\title{
Androgen receptor expression predicts beneficial tamoxifen response in oestrogen receptor- $\alpha$-negative breast cancer
}

\author{
Erik Hilborn ${ }^{1}$, Jelena Gacic ${ }^{1}$, Tommy Fornander ${ }^{2}$, Bo Nordenskjöld ${ }^{1}$, Olle Stål ${ }^{1,3}$ and Agneta Jansson ${ }^{*, 1}$ \\ ${ }^{1}$ Division of Clinical sciences, Department of Clinical and Experimental Medicine, Faculty of Health Sciences, Linköping University, \\ Linköping S-581 85, Sweden; ${ }^{2}$ Department of Oncology-Pathology, Karolinska Institute, Stockholm, Sweden and ${ }^{3}$ Department of \\ Oncology, Faculty of Health Sciences, Linköping University, Linköping, Sweden
}

Background: Although the androgen receptor (AR) is frequently expressed in breast cancer, its relevance in the disease is not fully understood. In addition, the relevance of AR in determining tamoxifen treatment efficiency requires evaluation.

Purpose: To investigate the tamoxifen predictive relevance of the AR protein expression in breast cancer.

Methods Patients were randomised to tamoxifen $40 \mathrm{mg}$ daily for 2 or 5 years or to no endocrine treatment. Mean follow-up was 15 years. Hazard ratios were calculated with recurrence-free survival as end point.

Results: In patients with oestrogen receptor (ER)-negative tumours, expression of AR predicted decreased recurrence rate with tamoxifen (hazard ratio $(H R)=0.34 ; 95 \%$ confidence interval $(C l)=0.14-0.81 ; P=0.015$ ), whereas the opposite was seen in the $A R-\operatorname{group}(H R=2.92 ; 95 \% \mathrm{Cl}=1.16-7.31 ; P=0.022)$. Interaction test was significant $P<0.001$. Patients with triple-negative and $A R+$ tumours benefitted from tamoxifen treatment $(H R=0.12 ; 95 \% \mathrm{Cl}=0.014-0.95 P=0.044)$, whereas patients with $A R-$ tumours had worse outcome when treated with tamoxifen $(H R=3.98 ; 95 \% \mathrm{Cl}=1.32-12.03 ; P=0.014)$. Interaction test was significant $P=0.003$. Patients with $E R+$ tumours showed benefit from tamoxifen treatment regardless of $A R$ expression.

Conclusions: AR can predict tamoxifen treatment benefit in patients with ER - tumours and triple-negative breast cancer.

Breast cancer is a heterogeneous disease (Perou et al, 2000; Carey et $a l, 2006)$. Current clinical subgrouping is based on protein expression of oestrogen receptor alpha (ER), progesterone receptor $(\mathrm{PgR})$ and human epidermal growth factor receptor 2 (HER2) into three groups: Luminal $(\mathrm{ER}+, \mathrm{PgR}+/-, \mathrm{HER}+/-)$, HER2 amplified (ER,$- \mathrm{PgR}-, \mathrm{HER} 2+)$ and triple-negative breast cancer (TNBC: ER - , PgR - , HER2 - ). The ER + breast cancers constitute 70-80\% of all cases (Niemeier et al, 2010; Qi et al, 2012). Endocrine treatment is the primary treatment for these cases and improves patient outcome (Palmieri et al, 2014). ER - disease is heterogeneous and has poorer outcome (Prat et al, 2015). TNBC cases are difficult to treat and are associated with increased risk of recurrence and poor prognosis compared with other subtypes. The androgen receptor (AR) is frequently expressed in normal breast epithelium and in malignant breast tumours (up to 80\%; Moinfar et al, 2003; Park et al, 2010), its expression differs in breast cancer subtypes, with $84-95 \%$ in luminal, 50-63\% in HER2 amplified and $10-53 \%$ in TNBC (Chia et al, 2015). Despite the high prevalence, the role of $\mathrm{AR}$ in breast cancer is not fully understood. In breast cancer in vitro models, androgens induce either growth inhibition or increased proliferation (Birrell et al, 1995). This varying response is not clearly elucidated, but seems to be related to the expression of ER, PgR and HER2 (Cops et al, 2008; Peters et al, 2009; $\mathrm{Ni}$ et al, 2011). In ER + breast cancer cell lines, AR is reported to inhibit proliferation in a manner depending on the $\mathrm{ER} / \mathrm{AR}$ ratio, with a higher $\mathrm{AR}$ to $\mathrm{ER}$ ratio indicating a stronger inhibition of proliferation. This signalling is reported to be mediated through the oestrogen response element

*Correspondence: Dr A Jansson; E-mail: agneta.jansson@liu.se

Received 10 June 2015; revised 9 November 2015; accepted 26 November 2015; published online 7 January 2016

(c) 2016 Cancer Research UK. All rights reserved 0007 - 0920/16 
(Peters et al, 2009). Several studies have reported an improved patient outcome associated with increased AR expression in ER + breast cancer (Castellano et al, 2010; Park et al, 2011; Park et al, 2012; Qu et al, 2013; Vera-Badillo et al, 2013). In the ER - , AR + subgroup, AR has been reported to predict improved patient outcome (Agoff et al, 2003); however, AR has also been associated with worse outcome (Hu et al, 2011). The molecular apocrine microarray profile (ER - , AR + ) described by Farmer et al (2005) is associated with worse outcome in the material where it was first tested, but has also been associated with favourable outcomes (Lakis et al, 2014). In ER - and HER2 + cell lines, AR activated the Wnt and HER2 pathways, and induced proliferation (Ni et al, 2011). In addition, AR and HER2 are positively correlated in several breast cancer cohorts (Micello et al, 2010; Niemeier et al, 2010; Park et al, 2011). TNBC is a diverse group, which is difficult to treat with high risk of recurrence and poor prognosis compared with other subtypes. However, the TNBC AR + group has been shown to respond to $\mathrm{AR}$ antagonists, and in addition a portion of these express the luminal AR gene expression profile, which resembles that of ER + breast cancer (Lehmann et al, 2011; Chia et al, 2015). Further, several reports on TNBC indicate a positive correlation between $\mathrm{AR}$ expression and better clinical outcome (Rakha et al, 2007; He et al, 2012; Tang et al, 2012; Thike et al, 2013).

Tamoxifen is a selective ER modulator (SERM) used to treat $\mathrm{ER}+$ breast cancer resulting in improved outcome. Patients with ER - breast cancer generally do not respond to this therapy, however, there is a fraction that does respond (McGuire, 1975; E.B.C.T.C.G, 1992, 1998). The relevance of AR in determining tamoxifen treatment efficiency is not fully elucidated, with opposing findings complicating the clinical relevance. In one study by Park et al (2012), AR status was shown to be a positive factor in determining treatment response to tamoxifen in patients with $\mathrm{ER}+$ breast cancer, on the other hand, using an in vitro model, (De Amicis et al (2010) showed that increased AR to ER ratio was an indicator of tamoxifen resistance.

The aim of this study was to investigate the prognostic (defined as outcome irrespective of treatment status) and tamoxifen predictive (defined as outcome influenced by treatment) relevance of AR protein expression in breast cancer and its subgroups. This was done using a retrospective cohort of lymph node-negative postmenopausal breast cancer patients with a long follow-up period that were randomised to no endocrine treatment or tamoxifen treatment, independently of ER expression.

\section{PATIENTS AND METHODS}

The present study was designed and presented with regard to the reporting recommendations for tumour marker prognostic studies (REMARK) guidelines (McShane et al, 2006).

Patient material. This retrospective cohort study was conducted using tumours from patients participating in a randomised tamoxifen trial conducted during 1976-1990 in Stockholm, Sweden. Results and details of the 'Stockholm Trial' were previously described (Rutqvist et al, 2007). All patients were post-menopausal with tumours $\leqslant 30 \mathrm{~mm}$ and were negative for axillary lymph node involvement $\left(N_{0}\right)$. The patients received either breast-conserving surgery followed by radiation treatment with a dose of 50 Gy with 2 Gy per fraction 5 days weekly or modified radical mastectomy. After surgery, patients were randomised to tamoxifen $40 \mathrm{mg}$ daily or to no endocrine treatment. After 2 years of tamoxifen treatment, most disease-free patients were randomised to tamoxifen for an additional 3 years or no further therapy. Tumour material from 912 women was available for the current investigation. The mean follow-up period for all patients was 15 years, for patients evaluated for AR the follow-up was 14 years and the mean follow-up until a recurrence occurred was 6 years. A retrospective study of biomarkers was approved by the Research Ethics Committee at the Karolinska Institute (dnr 97-451, with amendments). To conduct tissue microarray analysis, a pathologist selected representative parts of the tumours. Three tissue cores per patient with a diameter of $0.8 \mathrm{~mm}$ were chosen and transferred to paraffin blocks using a manual arrayer (Beecher Instruments, Sun Prairie, WI). From these blocks, sections were cut and placed on slides, forming the basis of the tissue microarray. ER and PgR status were determined with cutoff levels at $1 \%$ and $10 \%$ of positively stained tumour cell nuclei, respectively. For ER, the original cytosol measurements were used in the case of missing immunohistochemical data, with a cutoff of $0.05 \mathrm{fmol} \mu \mathrm{g}^{-1} \mathrm{DNA}$ (71 (9\%) of ER cases; Rutqvist et al, 2007). HER2 expression scored 0-3 + was previously described (Jansson et al, 2009), and for all analysis in this paper, the clinically used $3+$ expression was considered HER2 + . Grade was scored previously according to the Nottingham grade system (Jerevall et al, 2011).

Determination of AR expression through immunohistochemistry. Deparaffinisation, rehydration and antigen retrieval were accomplished using the Pre-Treatment Module for Tissue Specimens (DAKO, Glostrup, Denmark) with Buffer Envision FLEX (Target Retrieval Solution; DAKO) for high $\mathrm{pH}$, and treated according to the manufacturer's instructions. Endogenous peroxidases were blocked with $3 \% \mathrm{H}_{2} \mathrm{O}_{2}+\mathrm{MeOH}$ for $5 \mathrm{~min}$, washed in PBS and treated with Protein Block (DAKO) for $10 \mathrm{~min}$. The primary antibody, monoclonal mouse anti-human AR (DAKO, clone AR441), was diluted 1:400 and applied to the tissue sections and incubated overnight at $4{ }^{\circ} \mathrm{C}$. The slides were washed and a secondary antibody, DAKO Envision + System HRP K4000 Anti-Mouse (DAKO), was applied to the slides and incubated for $30 \mathrm{~min}$ at room temperature. The slides were stained with 3.3-diaminobenzidin hydrochloride $/ \mathrm{H}_{2} \mathrm{O}_{2}$ and incubated for $8 \mathrm{~min}$. After washing, the tissue sections were counterstained with Mayer's Haematoxylin (Sigma-Aldrich, St Louis, MO, USA), dehydrated and mounted with Pertex (Histolab, Göteborg, Sweden).

Sample scoring was done without knowledge of clinical or pathological data for patients. The tumour cell nuclei were scored and the occurrence of positive nuclei was divided into three groups, $0 \%(-) ; 1-10 \%(+)$ and $>10 \%(++)$. Two investigators (JG and $\mathrm{AJ}$ ) evaluated all slides independently with a concordance rate of $97 \%$. In the remaining $3 \%$ of cases, both evaluators re-evaluated the sample jointly to reach a consensus. Intra-patient heterogeneity was present in $\sim 1 \%$ of cases, and in these cores the choice was made to only evaluate the core with the highest percentage of stained cells in these cases. Representative slides were photographed using an Axio cam ICc5 digital camera (Zeiss, Oberkochen, Germany) using the AxioVision software (Zeiss). Validation of the antibody is described in the Supplementary Materials.

Statistical analysis. The relationships between grouped variables were analysed using Spearman's rank order correlation. To compensate for multiple testing, $P<0.01$ was set as significant. The survival curves were produced according to the life table method described by Kaplan and Meier, and differences between groups were evaluated with Gehan's generalised Wilcoxon test. Patients with missing data were excluded. Univariate and multivariate analyses were conducted using Cox proportional hazards regression and $P<0.05$ was considered significant. The chosen end point was recurrence, defined as regional relapse or distant metastasis. Breast cancer-specific survival was chosen as a secondary end point. The statistical package Statistica 12.0 (StatSoft Scandinavia, Uppsala, Sweden) was used for all calculations with the exception of the comparison of the TMA and the 
original cohort, where STATA 13.1 (StataCorp, Stocholm, Sweden) was used.

\section{RESULTS}

AR expression in breast cancer. Using immunohistochemistry, the expression of AR was analysed in tumours from 912 patients. A flow-chart of patients included in the initial tamoxifen trial and further included in the current analysis is shown in (Supplementary Figure 1). The patient selection available as TMA resembles the original patient cohort in terms of recurrence rate comparing the two treatment arms (hazard ratio $(\mathrm{HR})=0.623$ $95 \%$ confidence interval $(\mathrm{CI})=0.486-0.799 ; P<0.001$ compared with $\mathrm{HR}=0.67895 \% \mathrm{CI}=0.571-0.805 ; P<0.001)$ for the TMA and original cohort, respectively. Similar results were also acquired when selecting for only $\mathrm{ER}+$ cases $(\mathrm{HR}=0.581 ; \mathrm{CI}=0.436-0.773$; $P<0.001$ and $\mathrm{HR}=0.612 ; \mathrm{CI}=0.498-0.752 ; P<0.001)$ for the TMA and original cohort, respectively (Supplementary Figure 2). The patient and tumour characteristics were also similar (supplementary Table 1). The specificity of the anti-AR antibody was determined using western blot, where a single band at $110 \mathrm{kDa}$ was detected, which corresponds to the size of AR in western blot (Supplementary Figure 3). Tissue microarrays from 769 (84.3\%) patients were successfully scored, of these, $372(48.4 \%)$ patients did not receive any endocrine treatment and 397 (51.6\%) patients received tamoxifen treatment. There were $136(17.7 \%)$ cases with $0 \%$ AR expression $(-), 33(4.3 \%)$ cases showed AR expression in $1-10 \%$ of the tumour cells $(+)$, and $601(78 \%)$ cases showed AR expression in $>10 \%$ of the tumour cells $(++$; Table 1$)$. Representative images of immunohistochemical staining of AR

Table 1. Expression of androgen receptor in relation to clinicopathological characteristics

\begin{tabular}{|c|c|c|c|c|c|}
\hline & \multicolumn{4}{|c|}{$A R, n(\%)$} & \multirow{2}{*}{$P$-values } \\
\hline & $n$ & - & + & ++ & \\
\hline & 770 & $136(17.7)$ & $33(4.3)$ & $601(78.0)$ & \\
\hline \multicolumn{6}{|l|}{ Tumour size } \\
\hline$\leqslant 20 \mathrm{~mm}$ & 586 & 87 (14.9) & $25(4.3)$ & $474(80.9)$ & \multirow[t]{2}{*}{$P=0.0005$} \\
\hline$>20 \mathrm{~mm}$ & 166 & $44(26.5)$ & $8(4.8)$ & $114(68.7)$ & \\
\hline \multicolumn{6}{|c|}{ ER status $1 \%^{a}$} \\
\hline ER - & 160 & $76(47,5)$ & 12 (7.5\%) & $72(45)$ & \multirow[t]{2}{*}{$P<0.0001$} \\
\hline ER+ & 590 & $58(9.8)$ & $20(3.4)$ & $512(86,8)$ & \\
\hline \multicolumn{6}{|c|}{ PgR status $10 \%$} \\
\hline PR - & 326 & $95(29.1)$ & $21(6.4)$ & $210(64.4)$ & \multirow[t]{2}{*}{$P<0.0001$} \\
\hline $\mathrm{PR}+$ & 358 & $29(8.1)$ & $7(2.0)$ & $322(90.0)$ & \\
\hline \multicolumn{6}{|l|}{ HER2 status } \\
\hline $0-2+$ & 629 & 115 (18.3) & $27(4.3)$ & 487 (77.4) & \multirow{2}{*}{$P=0.38$} \\
\hline $3+$ & 82 & 12 (14.6) & $3(3.7)$ & $67(81.7)$ & \\
\hline \multicolumn{6}{|l|}{ Grade } \\
\hline 1 & 123 & $12(9.8)$ & $7(5.7)$ & $104(84.6)$ & \multirow[t]{3}{*}{$P<0.0001$} \\
\hline 2 & 381 & 48 (12.6) & $12(3.2)$ & $321(84.3)$ & \\
\hline 3 & 157 & $51(32.5)$ & $8(5.1)$ & $98(64.4)$ & \\
\hline \multicolumn{6}{|l|}{ Mitosis } \\
\hline 1 & 432 & $46(10.7)$ & $18(4.2)$ & $368(85.2)$ & \multirow[t]{3}{*}{$P=0.0001$} \\
\hline 2 & 103 & 20 (19.4) & $3(2.9)$ & $80(77.7)$ & \\
\hline 3 & 126 & $45(35.7)$ & $6(4.8)$ & $75(59.5)$ & \\
\hline \multicolumn{6}{|l|}{ Tamoxifen } \\
\hline No tamoxifen & 373 & 64 (17.1) & $19(5.1)$ & $290(77.8)$ & \multirow[t]{2}{*}{$P=0.54$} \\
\hline Tamoxifen & 397 & $72(18.1)$ & $14(3.5)$ & 311 (78.3) & \\
\hline \multicolumn{6}{|c|}{$\begin{array}{l}\text { Abbreviations: } A R=\text { androgen receptor, } E R=\text { oestrogen receptor, } P g R=\text { progesterone } \\
\text { receptor, } H E R 2=\text { human epithelial growth factor receptor } 2 \text {. } \\
a_{0.05} \text { fmol } \mu g^{-1} \text { DNA when no immunohistochemical data was available. Bold entries } \\
\text { indicate } P<0.05 \text {. }\end{array}$} \\
\hline
\end{tabular}

protein expression can be seen in (Supplementary Figure 4). There was a significant association of AR with ER $(P<0.0001)$ and $\mathrm{PgR}$ expression $(P<0.0001)$. There was an inverse correlation between AR expression and grade $(P<0.0001)$, mitotic index $(P<0.0001)$ and tumour size $(P=0.0005$; Table 1$)$. AR positivity varied based on hormone receptor and HER2 expression; 532 of 590 (90.2\%), 84 of $160(52.5 \%), 38$ of $46(82.6)$ and 28 of 87 (32.2) were AR + in $\mathrm{ER}+, \mathrm{ER}-$, HER2 amplified and TNBC tumours, respectively (Supplementary Table 2). Supplementary Table 2 shows AR frequency based on clinical subgrouping. In the group of ER tumours, AR expression was strongly correlated to high expression of HER2 $(P<0.0001)$. When analysing the prognostic and treatment predictive value of $A R, \geqslant 1 \%$ was considered positive.

\section{$A R$ and recurrence-free survival}

$A R$ predicts benefit from tamoxifen treatment in patients with $E R-$ tumours. For patients with ER - tumours and no tamoxifen treatment, AR was a negative prognostic factor $(\mathrm{HR}=2.64 ; \quad 95 \% \quad \mathrm{CI}=1.04-6.66 ; \quad P=0.040 ; \quad$ Figure 1 and Supplementary Table 3). In univariate analysis of ER - disease, $\mathrm{AR}+$ cases were associated with a beneficial tamoxifen response $(\mathrm{HR}=0.34 ; 95 \% \mathrm{CI}=0.14-0.81 ; P=0.015)$, the opposite was observed in patients with $\mathrm{AR}-$ tumours $(\mathrm{HR}=2.9295 \% \mathrm{CI}$ $1.16-7.31 ; P=0.022$ ), test for interaction $P<0.001$ (Figure 2 and Table 2). Furthermore, a multivariate interaction test between tamoxifen and AR adjusting for tumour size and grade was significant $(P=0.002)$. AR expression was not a prognostic factor in patients with $\mathrm{ER}-$ and HER2 + tumours (HR $=1.32 ; 95 \%$ $\mathrm{CI}=0.16-10.59 ; P=0.795)$ and AR could not predict tamoxifen treatment outcome in this group (Supplementary Table 3 and Table 2).

$A R$ is a prognostic marker in patients with TNBC. In the subgroup of tamoxifen untreated patients with TNBC, high AR expression was associated with poor prognosis $(\mathrm{HR}=3.80 ; 95 \%$ $\mathrm{CI}=1.11-12.99 ; P=0.033$; Figure 3 and Supplementary Table 3 ). Tamoxifen treatment benefit was seen in TNBC patients with tumours positive for $\mathrm{AR} \quad(\mathrm{HR}=0.12 ; 95 \% \mathrm{CI}=0.014-0.95$ $P=0.044)$, whereas those with tumours without AR expression had increased recurrence rate if treated with tamoxifen $(\mathrm{HR}=3.98$; 95\% CI $=1.32-12.03 ; P=0.014)$. The interaction test between tamoxifen and AR was significant $(P=0.003$; Figure 4 and Table 2).

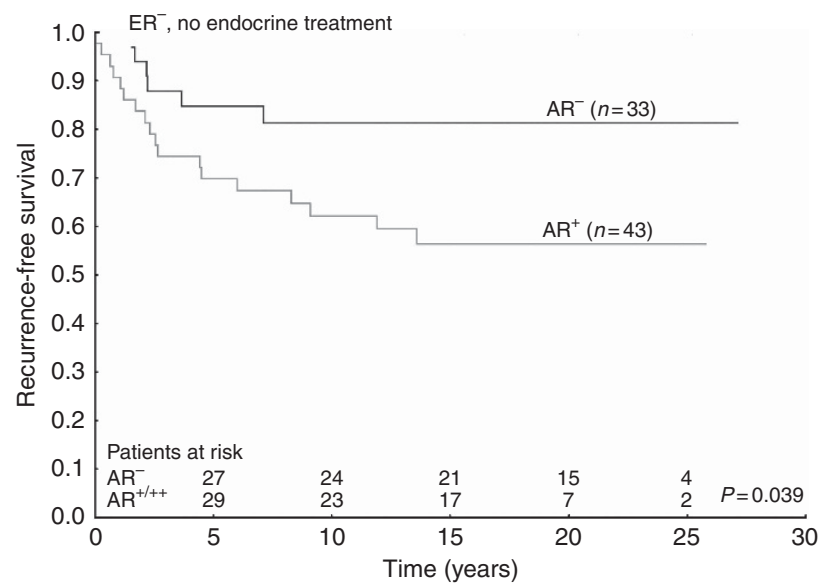

Figure 1. Survival curves with recurrence-free survival as end point for patients who did not receive endocrine treatment, grouped according to nuclear androgen receptor expression. All patient tumours were oestrogen receptor negative. 
$A R$ expression in patients with ER+ tumours with or without tamoxifen treatment. In patients with $\mathrm{ER}+$ tumours without tamoxifen treatment, no significant difference was found when
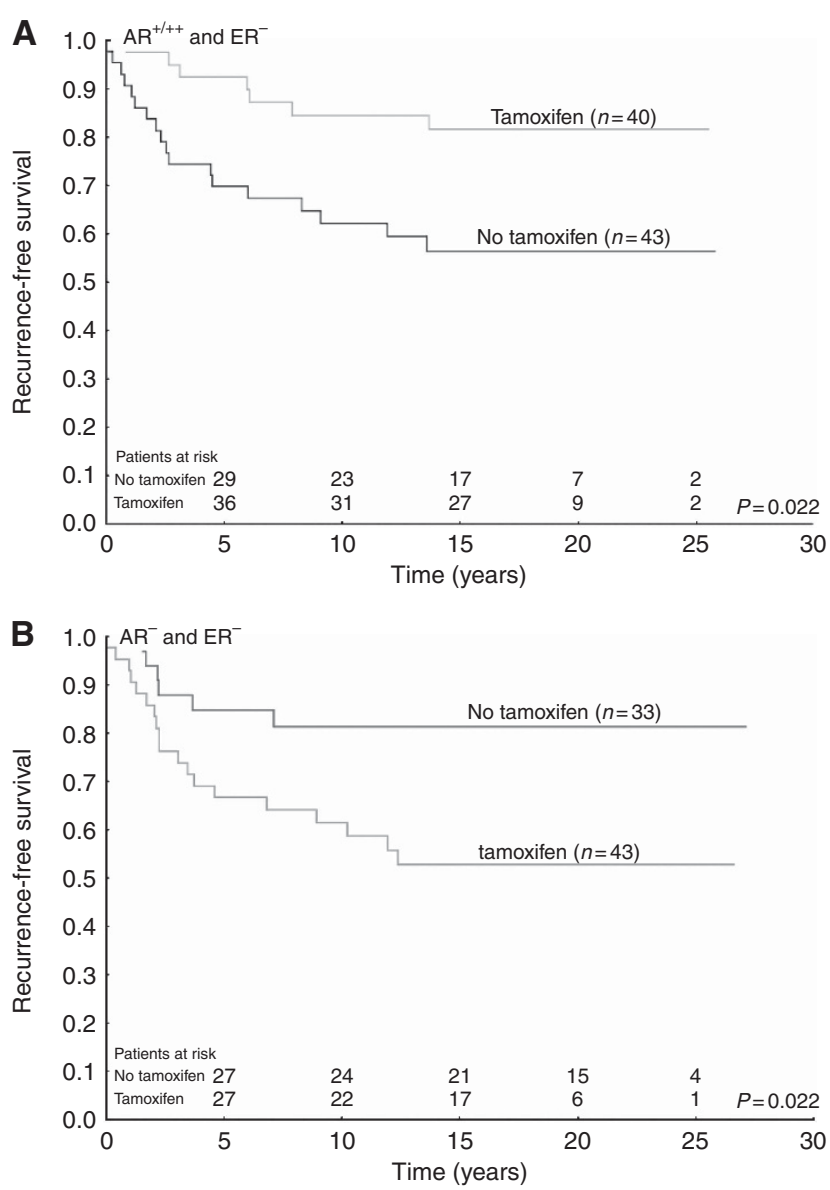

Figure 2. Survival curves with recurrence-free survival as end point, grouped according to treatment status. All patient tumours were oestrogen receptor negative. (A) Patients with $\geqslant 1 \%$ androgen receptor expression; (B) Patients with no androgen receptor expression. grouped by AR status $(P>0.05$; Supplementary Figure 5 and Supplementary Table 3). Patients with ER + tumours showed benefit from tamoxifen regardless of $\mathrm{AR}$ expression (Supplementary Figure 6 and Table 2).

AR expression and breast cancer-specific survival. In terms of prognosis, AR had no significant impact on breast cancer-specific survival in either of the tested subgroups; however, there was a trend for ER - and TNBC patients to have worse outcome when $\mathrm{AR}+$ (Supplementary Table 3). When treated with tamoxifen, patients with $\mathrm{ER}-$ and $\mathrm{AR}-$ tumours had increased risk $(\mathrm{HR}=3.04 ; 95 \% \mathrm{CI}=1.00-9.25 ; P=0.049)$, as did TNBC AR patients $(\mathrm{HR}=3.97 ; 95 \% \mathrm{CI}=1.12-14.10 ; P=0.033)$. The test for interaction between tamoxifen and AR was significant for both the ER - and TNBC groups $(P=0.004$ and 0.009 , respectively; Table 2). There was a benefit for $\mathrm{ER}+$ and $\mathrm{AR}+$ patients $(\mathrm{HR}=0.43 ; 95 \% \mathrm{CI}=0.27-0.70 ; P=0.001)$; however, there was a similar trend towards benefit in the $\mathrm{AR}-$ group, and the interaction test was not significant (Table 2).

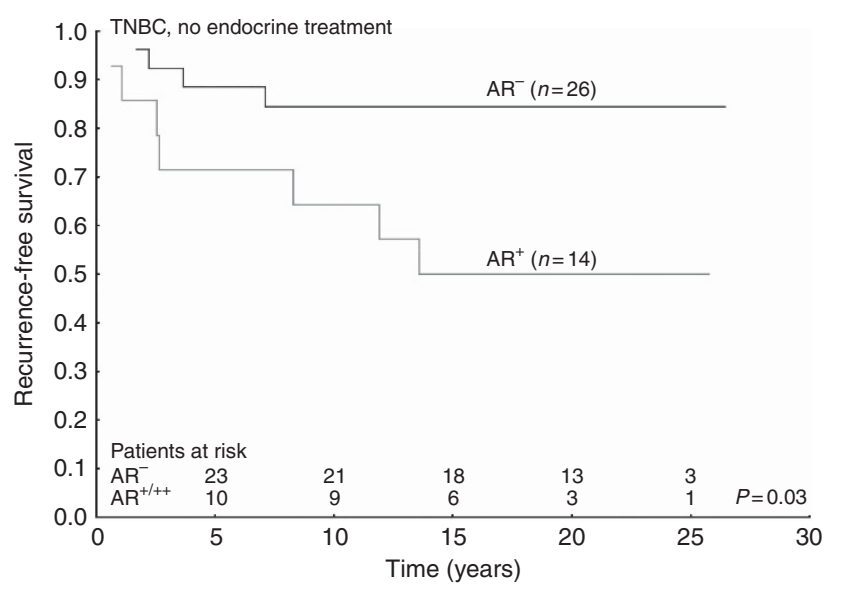

Figure 3. Survival curves with recurrence-free survival as end point for patients who did not receive endocrine treatment, grouped according to nuclear androgen receptor expression. All patient tumours were triple negative (oestrogen receptor, progesterone receptor and epidermal growth factor receptor 2 negative).

Table 2. Risk based on tamoxifen treatment status

\begin{tabular}{|c|c|c|c|c|c|c|c|}
\hline & HR $(95 \% \mathrm{Cl})$ & $P$ & $\mathrm{Pi}$ & & $\operatorname{HR}(95 \% \mathrm{Cl})$ & $P$ & $\mathrm{Pi}$ \\
\hline ER - & & & $<0.001$ & ER - & & & 0.004 \\
\hline$A R+(n=83)$ & $0.34(0.14-0.81)$ & 0.015 & & $A R+(n=83)$ & $0.48(0.18-1.28)$ & 0.144 & \\
\hline ER - HER2 + & & & 0.946 & ER - HER2 + & & & 0.794 \\
\hline TNBC & & & 0.003 & TNBC & & & 0.009 \\
\hline$A R-(n=58)$ & $4.14(1.38-12.41)$ & 0.011 & & $A R-(n=59)$ & $3.97(1.12-14.10)$ & 0.033 & \\
\hline$A R+(n=28)$ & $0.12(0.01-0.95)$ & 0.044 & & $A R+(n=28)$ & $0.18(0.02-1.53)$ & 0.115 & \\
\hline ER + & & & 0.531 & ER + & & & 0.935 \\
\hline
\end{tabular}



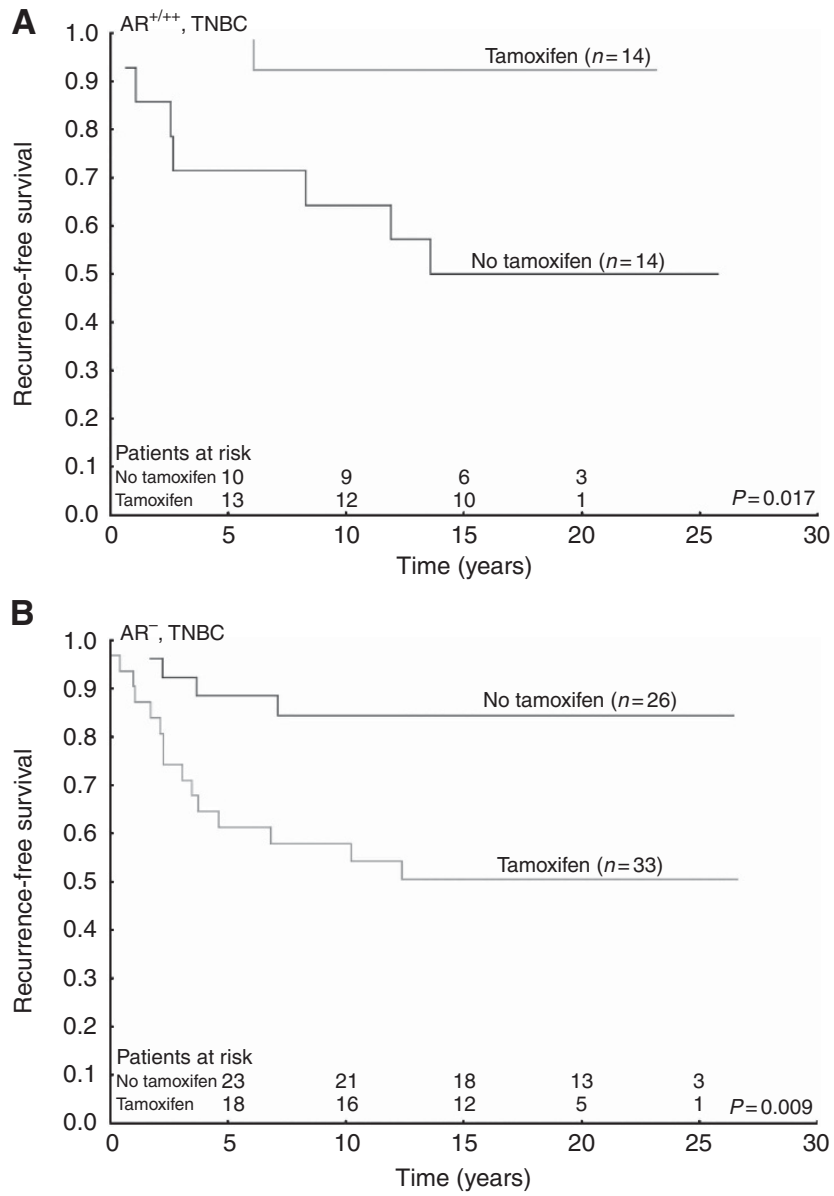

Figure 4. Survival curves with recurrence-free survival as end point, grouped according to treatment status. All patient tumours were triple negative. (A) Patients with $\geqslant 1 \%$ androgen receptor expression; (B) patients with no androgen receptor expression.

\section{DISCUSSION}

Here, we present the findings of a large retrospective cohort of nodal negative, low-risk breast cancer patients who were randomised to endocrine or no endocrine treatment independently of ER status. We demonstrate a negative relationship of AR expression with tumour size, grade and mitotic index, and a positive correlation with ER and PR, and in ER - tumours, with HER2, all of which is consistent with similar studies (Gonzalez-Angulo et al, 2009; Mrklic et al, 2013; Shibahara et al, 2013; Elebro et al, 2014). In this study, AR expression was detected in $82 \%$ of the tumours, previous studies observed that the frequency of $\mathrm{AR}+$ breast cancer in $58.8-90.5 \%$ of cases (Niemeier et al, 2010; Hu et al, 2011; Park et al, 2011; Elebro et al, 2014). The different percentages of $\mathrm{AR}+$ tumours may depend on use of different antibodies, use of paraffin embedded or frozen sections and varying cutoff values.

We gained similar results regardless of whether we used $\geqslant 1 \%$ or $\geqslant 10 \%$ cutoff for AR when conducting survival analysis. However, there was slightly better significance when $\geqslant 1 \%$ nuclei stained was used. As $1 \%$ cutoff is the current standard for ER, and a large number of studies regarding the role of $A R$ also use this cutoff, it was chosen for all survival analyses in the current study (Rakha et al, 2007; Castellano et al, 2010; $\mathrm{Hu}$ et al, 2011; Thike et al, 2013; Choi et al, 2015).

ER - breast cancers are difficult to treat, and have poorer outcome than ER + disease (Prat et al, 2015). Here we show that the ER - AR + cases have worsened outcome. A similar trend was shown previously in the Nurses' Health study for breast cancerspecific survival ( $\mathrm{Hu}$ et al, 2011). Adverse outcome was also seen using the molecular apocrine profile on the Van 't Veer and Sorlie data sets (Farmer et al, 2005). In addition, a recent publication showed a connection between AR negativity and increased expression of metabolic proteins, which correlated with worse outcome (Noh et al, 2014). Peters et al (2009) and Tokunaga et al (2013) failed to show any significance of AR in terms of prognosis when using $75 \%$ cutoff for AR. Improved survival was seen in a small $(n=69)$ cohort of primarily high-grade and metastatic ER cases (Agoff et al, 2003). Two recent meta-analyses have shown that AR positivity is a positive prognostic factor in ER - and ER + breast cancer (Qu et al, 2013; Vera-Badillo et al, 2013). However, the selection appears somewhat biased as no studies were included that indicate AR as a negative factor. In addition, many of the patients in both meta-analyses were of Asian descent, which could indicate that the role of AR may differ in different populations. We show that the ER - and AR + subgroup of patients benefitted from tamoxifen in terms of recurrence, with a similar trend in terms of breast cancer-specific survival, whereas patients who were both $\mathrm{ER}-$ and $\mathrm{AR}-$ fared worse on adjuvant tamoxifen treatment in terms of both recurrence and breast cancer-specific survival. One explanation for this could be the ability of tamoxifen to bind directly to AR (Fang et al, 2003). In prostate cancer, tamoxifen was shown to inhibit AR activity and cell replication (Mangerini et al, 2012; Piccolella et al, 2013) and the selective ER downregulator fulvestrant effectively downregulated $\mathrm{AR}$ and induced growth inhibition in several human prostate cancer cells (Bhattacharyya et al, 2006). These results suggest an antiandrogenic effect of anti-oestrogens. Our finding may have clinical implications and we suggest that tamoxifen and possibly other anti-oestrogens should be evaluated in breast cancer patients with $\mathrm{ER}$ - but AR + tumours.

To evaluate the impact of HER2 expression on the role of AR in ER - patients, we examined the ER - and HER2 + subgroup. We found no significant change in outcome based on AR expression, which could be attributed to the small sample size $(n=21)$. Lin Fde et al (2012) reported increased grade in the AR and ER - HER2 + cohort.

TNBC cases are heterogeneous and have poor prognosis. There is a strong need to find better therapeutic targets for these patients. Our results indicate that high AR expression was associated with worse outcome, which is supported by previous findings (Choi et al, 2015; Luo et al, 2010). However, others report no role of AR expression (McGhan et al, 2013), or improved outcome in AR+ TNBC (Rakha et al, 2007; He et al, 2012; Tang et al, 2012; Thike et al, 2013). There is no clear indicator as to why these studies have opposing results, the number of patients with high grade, metastatic and nodal involvement varied somewhat between studies, as did AR cutoff value and the fraction of $\mathrm{AR}+$ patients, which ranged from 13 to $25.8 \%$. We did notice a trend towards lower grade and less metastasis and nodal involvement in the studies where $\mathrm{AR}$ was an indicator of poor prognosis. In $\mathrm{AR}+$ TNBC cases, tamoxifen treatment provided significantly improved outcome. Of note is the adverse outcome in the AR - cases, who fared worse on tamoxifen treatment in both outcomes studied. In the current cohort, 28 TNBC patients were $\mathrm{AR}+$, and a larger patient cohort is needed to strengthen these results.

No prognostic impact of AR expression in ER + patients was observed, despite this being reported previously by several groups for ER + patients (Castellano et al, 2010; Park et al, 2011; Park et al, 2012; Qu et al, 2013). It is worth noting several differences between this and many previously published studies in terms of prognosis, where this study presents findings from patients with nodal negative disease who did not receive endocrine treatment. Many of the authors reporting that AR expression correlated to 
positive outcome analysed more heterogeneous patient groups in terms of stage, age and endocrine treatment status (Peters et al, 2009; Niemeier et al, 2010; Hu et al, 2011; Park et al, 2011; Elebro et al, 2014).

The beneficial effects of tamoxifen treatment in ER + patients remained regardless of AR status. And although an improvement in breast cancer-specific survival was seen in the current cohort, the AR - group had a similar trend, and the interaction test was not significant. In a previous study, AR status predicted good response to tamoxifen in ER + patients (Park et al, 2012). However, these findings are from a cohort with different AR cutoffs and higher grade in the patient population as compared with ours, complicating comparison of results. De Amicis et al (2010) demonstrated that AR may constitute a possible mechanism for tamoxifen resistance, however, these findings are based on in vitro analysis and a small $(n=9)$ patient sample and no such association could be detected in the present study.

Although the ability to target AR using SERMs opens for further treatment options, the clinical benefit of anti-androgen treatment in $\mathrm{AR}+$ patients was shown 40 years ago in metastatic breast cancer upon the administration of dihydrotestosterone and fluoxymesterone (Goldenberg, 1964; Goldenberg et al, 1975; Manni et al, 1981). Despite the advantages, these treatments fell out of use because of virilising side effects, and the advent of SERMs. Recently, the ER - and AR + group has been shown to benefit from modern androgen therapy (Doane et al, 2006). Further, Lehmann et al (2011) showed that TNBC and AR + cells responded well to the $\mathrm{AR}$ antagonist bicalutamide. A clinical trial examining the clinical outcome of bicalutamide in stage IV patients with $\mathrm{AR}+$ and $\mathrm{ER}$ and $\mathrm{PgR}$ - disease (NCT00468715) was completed recently, the results indicating that the treatment was well-tolerated and yielded clinical benefit (Gucalp et al, 2013). Two phase 2 clinical trials (NCT02353988 and NCT02348281) are evaluating the benefit of bicalutamide in TNBC, the results of these studies are eagerly awaited. In addition, the first preview of the results of clinical trial NCT01889238 studying the effect of Enzalutamide in TNBC was presented recently, indicating clinical benefit Traina et al (2015). In addition to ER - cohorts, Overmoyer (2014) show that targeting the AR utilising the selective AR modulator Enobosarm in ER + breast cancer was welltolerated and has significant clinical benefit. These new treatment options provide an important opportunity in the treatment of $\mathrm{AR}+$ patients.

Known limitations of this study are that the use of retrospective materials could infer a potential bias on patient selection for the current study. Furthermore, although no known bias exists for the patients who were included in this study for which no AR staining could be made, it is not possible to determine if these patients would alter the results. In addition, the tamoxifen administration performed in this study follows an older clinical approach of $40 \mathrm{mg}$ daily, compared with $20 \mathrm{mg}$ daily, which is the current standard, this could reduce the external validity of these findings. Another possible result of the higher dose of tamoxifen could be increased AR antagonism, compared with $20 \mathrm{mg}$ (Mangerini et al, 2012; Piccolella et al, 2013). In this study, $\geqslant 1 \%$ ER was designated as positive, which is the clinical practice in several countries, however, similar results were obtained when $\geqslant 10 \%$ ER was set as the limit for ER positivity.

\section{CONCLUSION}

We show that AR status might be used to identify a subgroup of patients with ER - tumours benefitting from adjuvant tamoxifen treatment. We interpret this to mean that patients with ER tumours may have their tumours tested for $\mathrm{AR}$ and could be candidates for tamoxifen therapy. We also identified a subgroup of patients with TNBC who had AR + tumours that may be treated with tamoxifen to improve outcome. These hypotheses generating observations need confirmation by further studies with larger number of ER - and TNBC patients in prospective cohorts.

\section{ACKNOWLEDGEMENTS}

We thank the patients who participated in this study. We also thank Lambert Skoog at Karolinska University Hospital, Stockholm, Sweden, for evaluating ER and HER2 staining and Dennis Sgroi at the Harvard Medical School for grading the material according to the Nottingham grade system. We thank Birgitta Holmlund for her help in constructing the tissue microarrays. This work was funded by generous grants from the Swedish research council, (grant number A0346701, http://www.vr.se) and the Swedish cancer foundation, grant number (13 0435, http:// www.cancerfonden.se).

\section{CONFLICT OF INTEREST}

The authors declare no conflict of interest.

\section{REFERENCES}

Agoff SN, Swanson PE, Linden H, Hawes SE, Lawton TJ (2003)

Androgen receptor expression in estrogen receptor-negative breast cancer. Immunohistochemical, clinical, and prognostic associations. Am J Clin Pathol 120(5): 725-731.

Bhattacharyya RS, Krishnan AV, Swami S, Feldman D (2006) Fulvestrant (ICI 182,780) down-regulates androgen receptor expression and diminishes androgenic responses in LNCaP human prostate cancer cells. Mol Cancer Ther 5(6): 1539-1549.

Birrell SN, Bentel JM, Hickey TE, Ricciardelli C, Weger MA, Horsfall DJ, Tilley WD (1995) Androgens induce divergent proliferative responses in human breast cancer cell lines. J Steroid Biochem Mol Biol 52(5): 459-467.

Carey LA, Perou CM, Livasy CA, Dressler LG, Cowan D, Conway K, Karaca G, Troester MA, Tse CK, Edmiston S, Deming SL, Geradts J, Cheang MC, Nielsen TO, Moorman PG, Earp HS, Millikan RC (2006) Race, breast cancer subtypes, and survival in the Carolina Breast Cancer Study. JAMA 295(21): 2492-2502.

Castellano I, Allia E, Accortanzo V, Vandone AM, Chiusa L, Arisio R, Durando A, Donadio M, Bussolati G, Coates AS, Viale G, Sapino A (2010) Androgen receptor expression is a significant prognostic factor in estrogen receptor positive breast cancers. Breast Cancer Res Treat 124(3): 607-617.

Chia K, O’Brien M, Brown M, Lim E (2015) Targeting the androgen receptor in breast cancer. Curr Oncol Rep 17(2): 4.

Choi JE, Kang SH, Lee SJ, Bae YK (2015) Androgen receptor expression predicts decreased survival in early stage triple-negative breast cancer. Ann Surg Oncol 22(1): 82-89.

Cops EJ, Bianco-Miotto T, Moore NL, Clarke CL, Birrell SN, Butler LM, Tilley WD (2008) Antiproliferative actions of the synthetic androgen, mibolerone, in breast cancer cells are mediated by both androgen and progesterone receptors. J Steroid Biochem Mol Biol 110(3-5): 236-243.

De Amicis F, Thirugnansampanthan J, Cui Y, Selever J, Beyer A, Parra I, Weigel NL, Herynk MH, Tsimelzon A, Lewis MT, Chamness GC, Hilsenbeck SG, Ando S, Fuqua SA (2010) Androgen receptor overexpression induces tamoxifen resistance in human breast cancer cells. Breast Cancer Res Treat 121(1): 1-11.

Doane AS, Danso M, Lal P, Donaton M, Zhang L, Hudis C, Gerald WL (2006) An estrogen receptor-negative breast cancer subset characterized by a hormonally regulated transcriptional program and response to androgen. Oncogene 25(28): 3994-4008.

E.B.C.T.C.G (1992) Systemic treatment of early breast cancer by hormonal, cytotoxic, or immune therapy. 133 randomised trials involving 31,000 
recurrences and 24,000 deaths among 75,000 women. Early Breast Cancer Trialists' Collaborative Group. Lancet 339(8784): 1-15.

E.B.C.T.C.G (1998) Tamoxifen for early breast cancer: an overview of the randomised trials. Early Breast Cancer Trialists' Collaborative Group. Lancet 351(9114): 1451-1467.

Elebro K, Butt S, Dorkhan M, Jernstrom H, Borgquist S (2014) Age at first childbirth and oral contraceptive use are associated with risk of androgen receptor-negative breast cancer: the Malmo Diet and Cancer Cohort. Cancer Causes Control 25(8): 945-957.

Fang H, Tong W, Branham WS, Moland CL, Dial SL, Hong H, Xie Q, Perkins R, Owens W, Sheehan DM (2003) Study of 202 natural, synthetic, and environmental chemicals for binding to the androgen receptor. Chem Res Toxicol 16(10): 1338-1358.

Farmer P, Bonnefoi H, Becette V, Tubiana-Hulin M, Fumoleau P, Larsimont D, Macgrogan G, Bergh J, Cameron D, Goldstein D, Duss S, Nicoulaz AL, Brisken C, Fiche M, Delorenzi M, Iggo R (2005) Identification of molecular apocrine breast tumours by microarray analysis. Oncogene 24(29): 4660-4671.

Goldenberg IS (1964) Testosterone propionate therapy in breast cancer. JAMA 188: 1069-1072.

Goldenberg IS, Sedransk N, Volk H, Segaloff A, Kelley RM, Haines CR (1975) Combined androgen and antimetabolite therapy of advanced female breast cancer. A report of the cooperative breast cancer group. Cancer 36(2): 308-310.

Gonzalez-Angulo AM, Stemke-Hale K, Palla SL, Carey M, Agarwal R, Meric-Berstam F, Traina TA, Hudis C, Hortobagyi GN, Gerald WL, Mills GB, Hennessy BT (2009) Androgen receptor levels and association with PIK3CA mutations and prognosis in breast cancer. Clin Cancer Res 15(7): 2472-2478.

Gucalp A, Tolaney S, Isakoff SJ, Ingle JN, Liu MC, Carey LA, Blackwell K, Rugo H, Nabell L, Forero A, Stearns V, Doane AS, Danso M, Moynahan ME, Momen LF, Gonzalez JM, Akhtar A, Giri DD, Patil S, Feigin KN, Hudis CA, Traina TA. Translational Breast Cancer Research C (2013) Phase II trial of bicalutamide in patients with androgen receptor-positive, estrogen receptornegative metastatic Breast Cancer. Clin Cancer Res 19(19): 5505-5512.

He J, Peng R, Yuan Z, Wang S, Peng J, Lin G, Jiang X, Qin T (2012) Prognostic value of androgen receptor expression in operable triplenegative breast cancer: a retrospective analysis based on a tissue microarray. Med Oncol 29(2): 406-410.

Hu R, Dawood S, Holmes MD, Collins LC, Schnitt SJ, Cole K, Marotti JD, Hankinson SE, Colditz GA, Tamimi RM (2011) Androgen receptor expression and breast cancer survival in postmenopausal women. Clin Cancer Res 17(7): 1867-1874.

Jansson A, Delander L, Gunnarsson C, Fornander T, Skoog L, Nordenskjold B, Stal O (2009) Ratio of 17HSD1 to 17HSD2 protein expression predicts the outcome of tamoxifen treatment in postmenopausal breast cancer patients. Clin Cancer Res 15(10): 3610-3616.

Jerevall PL, Ma XJ, Li H, Salunga R, Kesty NC, Erlander MG, Sgroi DC, Holmlund B, Skoog L, Fornander T, Nordenskjold B, Stal O (2011) Prognostic utility of HOXB13:IL17BR and molecular grade index in early-stage breast cancer patients from the Stockholm trial. Br J Cancer 104(11): 1762-1769.

Lakis S, Kotoula V, Eleftheraki AG, Batistatou A, Bobos M, Koletsa T, Timotheadou E, Chrisafi S, Pentheroudakis G, Koutras A, Zagouri F, Linardou H, Fountzilas G (2014) The androgen receptor as a surrogate marker for molecular apocrine breast cancer subtyping. Breast 23(3): 234-243.

Lehmann BD, Bauer JA, Chen X, Sanders ME, Chakravarthy AB, Shyr Y, Pietenpol JA (2011) Identification of human triple-negative breast cancer subtypes and preclinical models for selection of targeted therapies. J Clin Invest 121(7): 2750-2767.

Lin Fde M, Pincerato KM, Bacchi CE, Baracat EC, Carvalho FM (2012) Coordinated expression of oestrogen and androgen receptors in HER2-positive breast carcinomas: impact on proliferative activity. J Clin Pathol 65(1): 64-68.

Luo X, Shi YX, Li ZM, Jiang WQ (2010) Expression and clinical significance of androgen receptor in triple negative breast cancer. Chinese J Cancer 29(6): 585-590.

Mangerini R, Argellati F, Pfeffer U, Boccardo F (2012) Effects of bicalutamide and $4 \mathrm{OH}$-tamoxifen on androgen-regulated gene expression in the LNCaP cell line. Anticancer Res 32(12): 5323-5329.
Manni A, Arafah BM, Pearson OH (1981) Androgen-induced remissions after antiestrogen and hypophysectomy in stage IV breast cancer. Cancer 48(11): 2507-2509.

McGhan LJ, McCullough AE, Protheroe CA, Dueck AC, Lee JJ, Nunez-Nateras R, Castle EP, Gray RJ, Wasif N, Goetz MP, Hawse JR, Henry TJ, Barrett MT, Cunliffe HE, Pockaj BA (2013) Androgen Receptor-Positive Triple Negative Breast Cancer: A Unique Breast Cancer Subtype. Ann Surg Oncol 21(2): 361-367.

McGuire WL (1975) Current status of estrogen receptors in human breast cancer. Cancer 36(2): 638-644.

McShane LM, Altman DG, Sauerbrei W, Taube SE, Gion M, Clark GM. Statistics Subcommittee of NCIEWGoCD (2006) REporting recommendations for tumor MARKer prognostic studies (REMARK). Breast Cancer Res Treat 100(2): 229-235.

Micello D, Marando A, Sahnane N, Riva C, Capella C, Sessa F (2010) Androgen receptor is frequently expressed in HER2-positive, ER/PRnegative breast cancers. Virchows Archiv 457(4): 467-476.

Moinfar F, Okcu M, Tsybrovskyy O, Regitnig P, Lax SF, Weybora W, Ratschek M, Tavassoli FA, Denk H (2003) Androgen receptors frequently are expressed in breast carcinomas: potential relevance to new therapeutic strategies. Cancer 98(4): 703-711.

Mrklic I, Pogorelic Z, Capkun V, Tomic S (2013) Expression of androgen receptors in triple negative breast carcinomas. Acta Histochem 115(4): 344-348.

Ni M, Chen Y, Lim E, Wimberly H, Bailey ST, Imai Y, Rimm DL, Liu XS, Brown M (2011) Targeting androgen receptor in estrogen receptornegative breast cancer. Cancer Cell 20(1): 119-131.

Niemeier LA, Dabbs DJ, Beriwal S, Striebel JM, Bhargava R (2010) Androgen receptor in breast cancer: expression in estrogen receptor-positive tumors and in estrogen receptor-negative tumors with apocrine differentiation. Mod Pathol 23(2): 205-212.

Noh S, Kim JY, Koo JS (2014) Metabolic differences in estrogen receptornegative breast cancer based on androgen receptor status. Tumour Biol 35(8): 8179-8192.

Overmoyer B (2014) Enobosarm for the treatment of metastatic, estrogen and androgen receptor positive, breast cancer. Final results of the primary endpoint and current progression free survival. SABCS, Abstract No. 568.

Palmieri C, Patten DK, Januszewski A, Zucchini G, Howell SJ (2014) Breast cancer: current and future endocrine therapies. Mol Cell Endocrinol 382(1): 695-723.

Park S, Koo J, Park HS, Kim JH, Choi SY, Lee JH, Park BW, Lee KS (2010) Expression of androgen receptors in primary breast cancer. Ann Oncol 21(3): 488-492.

Park S, Koo JS, Kim MS, Park HS, Lee JS, Lee JS, Kim SI, Park BW, Lee KS (2011) Androgen receptor expression is significantly associated with better outcomes in estrogen receptor-positive breast cancers. Ann Oncol 22(8): $1755-1762$.

Park S, Park HS, Koo JS, Yang WI, Kim SI, Park BW (2012) Higher expression of androgen receptor is a significant predictor for better endocrineresponsiveness in estrogen receptor-positive breast cancers. Breast Cancer Res Treat 133(1): 311-320.

Perou CM, Sorlie T, Eisen MB, van de Rijn M, Jeffrey SS, Rees CA, Pollack JR, Ross DT, Johnsen H, Akslen LA, Fluge O, Pergamenschikov A, Williams C, Zhu SX, Lonning PE, Borresn-Dale AL, Brown PO, Botstein D (2000) Molecular portraits of human breast tumours. Nature 406(6797): 747-752.

Peters AA, Buchanan G, Ricciardelli C, Bianco-Miotto T, Centenera MM, Harris JM, Jindal S, Segara D, Jia L, Moore NL, Henshall SM, Birrell SN, Coetzee GA, Sutherland RL, Butler LM, Tilley WD (2009) Androgen receptor inhibits estrogen receptor-alpha activity and is prognostic in breast cancer. Cancer Res 69(15): 6131-6140.

Piccolella M, Crippa V, Messi E, Tetel MJ, Poletti A (2013) Modulators of estrogen receptor inhibit proliferation and migration of prostate cancer cells. Pharmacol Res 79C: 13-20.

Prat A, Pineda E, Adamo B, Galvan P, Fernandez A, Gaba L, Diez M, Viladot M, Arance A, Munoz M (2015) Clinical implications of the intrinsic molecular subtypes of breast cancer. Breast 24(Suppl 2): S26-S35.

Qi JP, Yang YL, Zhu H, Wang J, Jia Y, Liu N, Song YJ, Zan LK, Zhang X, Zhou M, Gu YH, Liu T, Hicks DG, Tang P (2012) Expression of the androgen receptor and its correlation with molecular subtypes in 980 chinese breast cancer patients. Breast Cancer (Auckl) 6: $1-8$. 
Qu Q, Mao Y, Fei XC, Shen KW (2013) The impact of androgen receptor expression on breast cancer survival: a retrospective study and metaanalysis. PLoS One 8(12): e82650.

Rakha EA, El-Sayed ME, Green AR, Lee AH, Robertson JF, Ellis IO (2007) Prognostic markers in triple-negative breast cancer. Cancer 109(1): 25-32.

Rutqvist LE, Johansson H. Stockholm Breast Cancer Study G (2007) Long-term follow-up of the randomized Stockholm trial on adjuvant tamoxifen among postmenopausal patients with early stage breast cancer. Acta Oncol (Stockholm, Sweden) 46(2): 133-145.

Shibahara Y, Miki Y, Sakurada C, Uchida K, Hata S, McNamara K, Yoda T, Takagi K, Nakamura Y, Suzuki T, Ishida T, Ohuchi N, Sasano H (2013) Androgen and androgen-metabolizing enzymes in metastasized lymph nodes of breast cancer. Hum Pathol 44(10): 2338-2345.

Tang D, Xu S, Zhang Q, Zhao W (2012) The expression and clinical significance of the androgen receptor and E-cadherin in triple-negative breast cancer. Med Oncol 29(2): 526-533.

Thike AA, Yong-Zheng Chong L, Cheok PY, Li HH, Wai-Cheong Yip G, Huat Bay B, Tse GM, Iqbal J, Tan PH (2013) Loss of androgen receptor expression predicts early recurrence in triple-negative and basal-like breast cancer. Mod Pathol 27(3): 352-360.

Tokunaga E, Hisamatsu Y, Taketani K, Yamashita N, Akiyoshi S, Okada S, Tanaka K, Saeki H, Oki E, Aishima S, Oda Y, Morita M,
Maehara Y (2013) Differential impact of the expression of the androgen receptor by age in estrogen receptor-positive breast cancer. Cancer Med 2(6): 763-773.

Traina TA, Miller K, Yardley DA, O'Shaughnessy J, Cortes J, Awada A, Kelly CM, Trudeau ME, Schmid P, Gianni L, García-Estevez L, Nanda R, Ademuyiwa Foluso Olabisi, Chan S, Steinberg JL, Blaney ME, Tudor IC, Uppal H, Peterson AC, Hudis CA (2015) Results from a phase 2 study of enzalutamide (ENZA), an androgen receptor (AR) inhibitor, in advanced $\mathrm{AR}+$ triple-negative breast cancer (TNBC). J Clin Oncol 33(Suppl): abstract 1003.

Vera-Badillo FE, Templeton AJ, de Gouveia P, Diaz-Padilla I, Bedard PL, Al-Mubarak M, Seruga B, Tannock IF, Ocana A, Amir E (2013) Androgen receptor expression and outcomes in early breast cancer: a systematic review and meta-analysis. J Natl Cancer Inst 106(1): djt319.

This work is published under the standard license to publish agreement. After 12 months the work will become freely available and the license terms will switch to a Creative Commons AttributionNonCommercial-Share Alike 4.0 Unported License.

Supplementary Information accompanies this paper on British Journal of Cancer website (http://www.nature.com/bjc) 